\title{
Evaluation of Insecticides against Bihar Hairy Caterpillar, Spilosoma obliqua Walk. on Blackgram, Vigna mungo (Linn.)
}

\author{
Mun mun Mohapatra* and P.K. Gupta
}

Department of Entomology, College of Agriculture, Narendra Deva University of Agriculture and Technology, Faizabad 224229, Uttar Pradesh, India

*Corresponding author

\section{A B S T R A C T}

\begin{tabular}{|l|}
\hline Ke y w o r d s \\
$\begin{array}{l}\text { Black gram, Bihar hairy } \\
\text { caterpillar, Triazophos, } \\
\text { Cost-Benefit ratio }\end{array}$ \\
\hline Article Info \\
\hline $\begin{array}{l}\text { Accepted: } \\
\text { 04 May } 2018 \\
\text { Available Online: } \\
\text { 10 June 2018 }\end{array}$ \\
\hline
\end{tabular}

\section{Introduction}

Pulses are rich source of protein and constitute an integral part of the vegetarian diet of the Indian people. Pulses are the second most important crops after cereals. Black gram or Urdbean, Vigna mungo (Linn.) contributes $10 \%$ of national pulses production, is rich source of protein and carbohydrates (Ali and Gupta, 2012). In India the area, production and productivity of urdbean are 32.15 lac ha, $17.66 \mathrm{lac}$ tonnes and $549 \mathrm{~kg} / \mathrm{ha}$, respectively (Khajuria et al., 2015). Black gram, Vigna mungo (Linn.), Family-Leguminosae popularly known as urd bean or mash kalai or black bean is native of India and the fourth important pulse crop with high nutritive value
(Singh, 2004). Uttar Pradesh is the most agriculturally important state in India with respect to staple food production. Black gram is a prominent rainy and summer season pulse crop in Uttar Pradesh with area 88,000ha, production 55.2 thousand MT and productivity $523 \mathrm{~kg} / \mathrm{ha}$ (Anonymous, 2016). The annual yield loss due to the insect pests has been estimated at about 30 per cent in Urd bean and Mung bean.

Bihar hairy caterpillar (Spilosoma obliqua Walk.) is a serious pest in Bihar, Uttar Pradesh, Punjab, Madhya Pradesh, Manipur and some other states. The third and onward instar larvae cause serious damages and significant reduction in yield (Hussain and Begum, 1995; Gupta and Bhattacharya, 2008). 
Successful control of this pest is very difficult due to certain levels of behavioural resistance to different classes of insecticides. Hence insecticide application has been one of the effective and quick methods for management of pest population in the field.

The present investigation was carried out to evaluate the effectiveness of insecticides against Bihar hairy caterpillar in Black gram, Vigna mungo (Linn.).

\section{Materials and Methods}

The field experiment was carried out at Students' Instructional Farm, Narendra Deva University of Agriculture and Technology, Kumarganj, Faizabad (U.P.) during kharif season of 2015 on urd bean variety NDU1.The experiment was laid out in randomized block design (RBD) with seven treatments including control having three replications.

All agronomic practices were followed as per recommendations. The efficacy of six insecticides viz. Indoxacarb 14.5 EC@ 75g a.i/ha, Imidacloprid 17.8 SL@ 30g a.i./ha, Thiamethoxam 25 WG@40g a.i./ha, Lambda cyahlothrin 5 EC@ 40gm a.i/ha, Triazophos 40 EC @ 250g a.i./ha and Azadirachtin 1500ppm@3ml/L were evaluated 3, 7 and 14 days after insecticide application. The population of bihar hairy caterpillar was recorded before and 3, 7 and 14 days after insecticide application.

\section{Results and Discussion}

The population of Bihar hairy caterpillar was varied from 11.00 to 15.20 per plant before application of insecticides. All the insecticides tested against Bihar hairy caterpillar (Spilosoma obliqua) were found significantly superior on an untreated control. Among the tested insecticides Triazophos40EC @ 250g a.i./ha was found superior over the rest of the insecticides with a per cent reduction of $100 \%$ in insect population after $3^{\text {rd }}$ day (Table 1). The next treatments in order of superiority were Lambda cyahlothrin 5 EC@ 40gm a.i/ha, Indoxacarb 14.5 EC@ 75g a.i/ha, Imidacloprid17.8 SL@30g a.i./ha) with mean reduction\% of bihar hairy caterpillar population 75.50, 68.80 and 61.00 were recorded respectively.

Thiamethoxam 25WG @ 40g a.i/ha and Azadirachtin 1500ppm@3ml/L gave equal results of $52.20 \%$ reduction in population. All the treatments were found significant superior over control $7^{\text {th }}$ days after insecticide application. Triazophos40EC @ 250g a.i./ha showed maximum reduction in population of bihar hairy caterpillar followed by Indoxacarb 14.5 EC@75g a.i/ha, Lambda cyahlothrin 5 EC@40gm a.i/ha, Imidacloprid 17.8 SL@ $30 \mathrm{~g}$ a.i./ha, Thiamethoxam 25WG @ 40g a.i/ha and Azadirachtin 1500ppm@ 3ml/L with mean reduction\% of bihar hairy caterpillar population 95.00, 90.00, 82.00 and $80.0,78.60$ and 60.60 respectively.

The treatments were found significant superior $14^{\text {th }}$ days after insecticide application but less effective than other two sprays $\left(3^{\text {rd }}\right.$ and $\left.7^{\text {th }}\right)$. Triazophos40EC @ 250g a.i./ha showed maximum reduction in population of bihar hairy caterpillar followed by Indoxacarb 14.5 EC@75g a.i/ha, Lambda cyahlothrin 5 EC@ 40gm a.i/ha, Thiamethoxam 25WG @ 40g a.i/ha and with mean reduction\% of bihar hairy caterpillar population 72.00, 68.00, 62.20 and 51.00 respectively. Imidacloprid 17.8 SL@ 30g a.i./ha and Azadirachtin 1500ppm@3m1/L showed least mean reduction\% of population of bihar hairy caterpillar i.e. 48.80 and 32.20 respectively. The seventh treatment control (Water spray) exceptionally found increasing Bihar hairy caterpillar population $28.00,48.80$ and 82.80 $3^{\text {rd }}, 7^{\text {th }}$ and $14^{\text {th }}$ days after insecticide application respectively. 
Table.1 Effect of insecticidal treatments on Bihar hairy caterpillar, Spilosoma obliqua (Walk.) population during Kharif season 2015

\begin{tabular}{|c|c|c|c|c|c|c|c|}
\hline \multirow[t]{4}{*}{ S. No. } & \multirow[t]{4}{*}{ Treatment } & \multirow{4}{*}{$\begin{array}{l}\text { Dose } \\
\text { (g.a.i./ha) }\end{array}$} & \multirow{4}{*}{$\begin{array}{l}\text { Pretreatment } \\
\text { counts/plants } \\
\text { Mean }\end{array}$} & \multicolumn{3}{|c|}{$\%$ reduction and increase $(+)$ of Bihar hairy caterpillar } & \multirow{4}{*}{$\begin{array}{l}\text { Overall mean \% } \\
\text { reduction }\end{array}$} \\
\hline & & & & \multicolumn{3}{|c|}{ After the spray } & \\
\hline & & & & 3 DAS & 7 DAS & 14 DAS & \\
\hline & & & & Mean & Mean & Mean & \\
\hline 1 & Indoxacarb $14.5 \mathrm{EC}$ & 75 & $14.80(3.89)$ & $68.80(\mathbf{8 . 2 9})$ & $90.00(\mathbf{9 . 4 9})$ & $62.20(\mathbf{7 . 8 9})$ & 73.66 \\
\hline 2 & Imidacloprid $17.8 \mathrm{SL}$ & 30 & $12.00(3.53)$ & $61.00(\mathbf{7 . 8 3})$ & 80.00 (8.97) & $48.80(6.97)$ & 63.26 \\
\hline 3 & Thiamethoxam $25 \mathrm{WG}$ & 40 & $13.20(3.69)$ & $52.20(\mathbf{7 . 1 9})$ & $78.60(\mathbf{8 . 8 8})$ & $51.10(\mathbf{7 . 1 8})$ & 60.63 \\
\hline 4 & Lambda cyahlothrin 5 EC & 40 & $11.00(3.38)$ & $75.50(\mathbf{8 . 7 1})$ & $82.00(\mathbf{9 . 0 7})$ & $68.00(\mathbf{8 . 2 8})$ & 75.16 \\
\hline 5 & Triazophos $40 \mathrm{EC}$ & 250 & $15.20(3.96)$ & $100.00(\mathbf{9 . 9 9})$ & $95.50(9.79)$ & $72.40(\mathbf{8 . 5 3})$ & 89.30 \\
\hline 6 & Azadiractin 1500 ppm & $3 \mathrm{ml} / 1 \mathrm{~L}$ & $14.00(3.78)$ & $52.20(7.21)$ & $60.60(7.78)$ & $32.20(\mathbf{5 . 7 1})$ & 48.33 \\
\hline \multirow[t]{3}{*}{7} & Control (Water spray) & - & $14.60(3.87)$ & $+28.00(\mathbf{5 . 2 5})$ & $+48.80(\mathbf{6 . 9 6})$ & $+82.80(9.10)$ & \multirow[t]{3}{*}{+53.20} \\
\hline & SEm \pm & & NS & 0.41 & 0.26 & 0.31 & \\
\hline & C. D. at $5 \%$ & & & 1.26 & 0.80 & 0.95 & \\
\hline
\end{tabular}

DAS= Days after spray

()$=$ Figures in parentheses indicates transformed value $(\square \mathrm{x}+0.5)$

Table.2 Economics and cost benefit-ratio of treatments

\begin{tabular}{|c|c|c|c|c|c|c|}
\hline Treatments & $\begin{array}{l}\text { Dose } \\
\text { (a.i./ha) }\end{array}$ & $\begin{array}{lr}\text { Cost } & \text { of } \\
\text { treatment } & \text { Rs/ha }\end{array}$ & Yield (q/ha) & $\begin{array}{l}\text { Saved yield due to } \\
\text { treatment (q/ha) }\end{array}$ & $\begin{array}{lll}\text { Benefit due } & \text { to } \\
\text { treatment }(\mathrm{Rs} / \mathrm{ha}) & \end{array}$ & Cost: benefit ratio \\
\hline Indoxacarb 14.5 EC & 75 & 1820 & 9.96 & 3.53 & 17650 & $1: 9.69$ \\
\hline Imidacloprid 17.8 SL & 30 & 1440 & 9.40 & 2.97 & 14850 & $1: 10.31$ \\
\hline Thiamethoxam 25 WG & 40 & 1380 & 8.63 & 2.20 & 11000 & 1: 7.97 \\
\hline Lambda cyahlothrin 5 EC & 40 & 1385 & 10.33 & 3.90 & 19500 & 1: 14.07 \\
\hline Triazophos 40 EC & 250 & 1320 & 12.50 & 6.07 & 30350 & $1: 22.99$ \\
\hline Azadiractin 1500 ppm & $3 \mathrm{ml} / 1 \mathrm{~L}$ & 1440 & 8.23 & 1.83 & 9150 & $1: 6.35$ \\
\hline Control (Water spray) & & & 6.43 & - & & \\
\hline
\end{tabular}

Price of seed Rs. 5000.00/q

Labour charges Rs.142/day/man

Sprayer Rent Rs.30/day 
In case of yield, all the treatments showed significant increase of yield. Highest grain yield was recorded (Table 2) in Triazophos40EC @ 250g a.i./ha treated plot (12.50 q/ha) closely followed by Lambda cyhalothrin 5 EC@ 40gm a.i/ha (10.33 q/ha), Indoxacarb 14.5 EC@75g a.i/ha (9.96q/ha), Imidacloprid17.8 SL@ 30g a.i./ha) (9.40 q/ha),Thiamethoxam 25 WG@ 40g a.i./ha (8.63q/ha) and Azadirachtin 1500ppm@ $3 \mathrm{ml} / \mathrm{L})(8.23 \mathrm{q} / \mathrm{ha})$. Highest cost-benefit ratio was observed in Triazophos $250 \mathrm{~g}$ a.i./ha (1:22.99) followed by Lambda cyahlothrin @ 40gm a.i/ha (1:14.07), Imidacloprid 30g a.i./ha (1:10.31), Indoxacarb @75g a.i/ha (1:9.69) and Thiamethoxam @ 40g a.i./ha (1:7.97) and Azadirachtin @ 3ml/L (1:6.35). Similar were finding by Mandal et al., 2013. The following order of the efficacy of the insecticides, in the descending order, was observed

$\mathrm{T}_{5}$ (Triazophos40EC @ 250g a.i./ha) $>\mathrm{T}_{4}$ (Lambda cyhalothrin 5 EC@ 40gm a.i/ha) > $\mathrm{T}_{1}$ (Indoxacarb 14.5 EC@ 75g a.i/ha) > $\mathrm{T}_{2}$ (Imidacloprid17.8 SL@ 30g a.i./ha) > T3 (Thiamethoxam 25 WG@ 40g a.i./ha) > $\mathrm{T}_{6}$ (Azadirachtin 1500ppm@3ml/L).

Triazophos40EC @ 250g a.i./ha was found significantly most effective insecticides. Lambda cyahlothrin 5 EC@ 40gm a.i/ha was the second most effective treatment. The least effective treatment was Azadirachtin 1500ppm@3ml/L. The maximum cost benefit ratio was obtained from Triazophos40EC @ 250g a.i./ha treated plots.

\section{References}

Ali, M. and Gupta, S. (2012). Carrying capacity of Indian agriculture pulse crops. Current Science, 102: 874- 88.

Anonymous, (2016). Directorate of Economics and Statistics. Department of Agriculture and Cooperation.

Gupta, G. and Bhattacharya, A. K. 2008. Assessing toxicity of post emergence herbicides to the Spilarctia obliqua Walker (Lepidoptera: Arctiidae). J. Pest Science. 81: 9- 15.

Hussain, M. and Begum, M. 1995. Food preference of jute hairy caterpillar Spilosoma obliqua (Walk.) on some varieties of jute. Bangladesh $J$. Entomology. 5(1 and 2): 57- 59.

Khajuria, S., Rai, A.K., Kumar, K.L.R., Jadav J.K. (2015). Evaluation of integrated pest management (IPM) module against sucking-pest of black gram under semiarid conditions. Insect Environment, 20(4): 126-132.

Mandal D., Bhowmik P. And Baral K. (2013). Evaluation of insecticides for the management of Bihar hairy caterpillar, Spilosoma obliqua Walk. (Lepidoptera: Arctiidae) in black gram (Vigna mungo L.). The Bioscan. 8(2): 429-431.

Singh, S. S. 2004. Crop Management, 3rd Ed. Kalyani Publishers, New Delhi, p. 574.

\section{How to cite this article:}

Mun mun Mohapatra and Gupta, P.K. 2018. Evaluation of Insecticides against Bihar Hairy Caterpillar, Spilosoma obliqua Walk. on Blackgram, Vigna mungo (Linn.). Int.J.Curr.Microbiol.App.Sci. 7(06): 605-608. doi: https://doi.org/10.20546/ijcmas.2018.706.069 